\title{
The mitochondrion as a hammer
}

\author{
Logan W. Cole ${ }^{*}$ (D)
}

\begin{abstract}
This is a review of Mitonuclear Ecology by Geoffrey E. Hill, which discusses the potential role of mitochondrial-nuclear (mitonuclear) interactions in key evolutionary processes.
\end{abstract}

Keywords: Evolution, Mitochondria, Mitonuclear interactions

\section{Main text}

In a way that is highly meta and perhaps ironic, there is some conflict over the importance of mitonuclear interactions in evolutionary biology. Geoffrey Hill's Mitonuclear Ecology (2019) is a compelling volume that takes bold positions in these ongoing debates and will surely inspire much work in the eponymous field. Its treatment of several topics in and around the area of mitonuclear interactions is accessible and carefully curated. The volume puts forward a coherent and intriguing worldview of eukaryotic evolution that centers the mitochondrion. It does, however, create some ambiguity between our established understanding and the author's fascinatingyet-debatable claims about the evolution of mitonuclear interactions and mitochondrial genomes, and their impact on eukaryotic evolution broadly considered. As the author makes very clear in the book's preface, this is not intended to be an unbiased summary of the subject but rather an overview of, and advocacy for, the centrality of mitonuclear interactions in eukaryotic evolution.

The bulk of this volume's first half provides an excellent introduction to the fundamentals of eukaryotic (nuclear and mitochondrial) genomes, the underlying cell biology of mitochondrial-nuclear interactions, the coevolution of the two compartments, and related areas. This portion is clearly intended as a way for organismal biologists of all levels to begin thinking about mitochondria at molecular and subcellular scales, but the treatment of coevolution,

${ }^{*}$ Correspondence: Iwcole@iu.edu

Department of Biology, Indiana University, Bloomington, IN, USA conflict, and cooperation also may help molecular and cell biologists think about mitochondria in an evolutionary context. The volume describes complicated concepts in intuitive terms and provides an accessible overview of the different kinds of relevant experiments; in doing so, it provides a fairly comprehensive framework for one to begin thinking about questions, and even formulating ideas for potential experiments, that meaningfully address the role of mitonuclear interactions in evolution. As someone whose doctoral dissertation work dealt with the evolution of mitochondrial genomes, it occurred to me that this sort of broad treatment that bridges evolutionary and molecular considerations of mitochondria would have come in handy during my qualifying exam.

The manner in which complicated concepts are articulated simply and with accessible language is mirrored by the quality of the figures throughout the text, which collapse large amounts of information and arcane concepts into wonderfully tidy and concise images. Early on, for example, there is a figure that manages to comprehensively explain the various trade-offs among an array of approaches that assess the consequences of mitonuclear mismatches; figures like this begin to provide an important foundation for meaningfully addressing real issues in the area. Throughout the volume, there are many figures that contain elegant line drawings which complement the text in a way that erases any remaining ambiguity in the basic premises and intricate hypotheses that are a part of this subject.

That being said, there were early parts of this book where, through either curious omission or questionable exuberance, the blurring between established

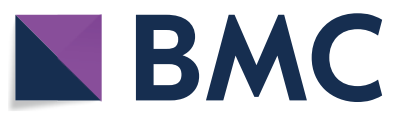

(c) The Author(s) 2020. This article is licensed under a Creative Commons Attribution 4.0 International License, which permits use, sharing, adaptation, distribution and reproduction in any medium or format, as long as you give appropriate credit to the original author(s) and the source, provide a link to the Creative Commons licence, and indicate if changes were made. The images or other third party material in this article are included in the article's Creative Commons licence, unless indicated otherwise in a credit line to the material. If material is not included in the article's Creative Commons licence and your intended use is not permitted by statutory regulation or exceeds the permitted use, you will need to obtain permission directly from the copyright holder. To view a copy of this licence, visit http://creativeco mmons.org/licenses/by/4.0/. The Creative Commons Public Domain Dedication waiver (http://creativecommons.org/publicdomain/ zero/1.0/) applies to the data made available in this article, unless otherwise stated in a credit line to the data. 
understanding and plausible but far-from-proven hypotheses occurs. For example, the book's reification of the mitochondrion as a pre- or co-requisite for eukaryogenesis following the work of Lane et al. (2005; Lane and Martin 2010) ignores a still-ongoing dialogue (Lynch and Marinov 2015, 2017; Hampl et al. 2019; Chiyomaru and Takemoto 2020; Lane 2020) about the energetic requirements of various eukaryotic features. Also, some framing of methods suggests that the field is better poised to address Hill's focal questions than it may be. When the volume discusses the merits of cybrid cell lines, it cites studies with cybrid pairs that are comparatively distantly related (e.g. Barrientos et al. 1998; Enoki et al. 1994) while the evolutionary questions dealt with in later chapters are those of population-level processes or at the precipice of speciation. Notably, the role of mitonuclear conflict is largely dismissed despite it being a potentially fruitful line of inquiry (Ågren 2013; Havird et al. 2019).

The latter portion of the book takes on a more polemic character, but, as such, deals with those controversial questions most interesting to evolutionary geneticists and presents thoughtful hypotheses, supported by varying degrees of evidence. Though one may disagree as to the relative importance of mitonuclear interactions in the evolution of sex, speciation, mate choice, senescence, and adaptive radiation, expounding upon these bold hypotheses is quite welcome here, as the goal of this part of book is clearly to advocate for preeminence of mitonuclear interactions in eukaryotic evolution. In some parts, however, this veers into an unfounded assuredness of the importance of mitonuclear interactions. For example, the author refers to mitonuclear coadaptation as "a precise and universal explanation for the evolution of genetic incompatibilities between populations," which is an incredibly bold claim that is nigh impossible to demonstrate.

On occasion the volume treats certain unproven or ungeneralizable hypotheses, including the aforementioned energetic necessity of mitochondria for complexity and mitonuclear species concept, mitonuclear mate choice, and the role of mitochondrial introgression in adaptation, as canonical parts of our knowledge or widely-applicable solutions to longstanding evolutionary problems. The author states that Nick Lane's 2005 book, Power, Sex, Suicide: Mitochondria and the Meaning of Life, prompted him to consider a greater role for the mitochondrion's subcellular processes in evolution. Clearly, this mitochondrion-centric framework is that in which the stances expressed in the latter half of the book were formulated. The adoption of this narrow analytical framework may have led to a pervasive Maslow's (1966) hammer bias, where the hammer is the mitochondrion and the nail is any of the various open questions of evolution as they pertain to eukaryotes.

Ostensibly, the scope of this book is all eukaryotes but most of the text is dedicated to metazoans with only brief digressions to discuss other groups. It may have better served the premise of the book to place complete focus on metazoans and to set aside these digressions, as they can be somewhat misleading or incomplete. For example, the book discusses a plausible and cogent hypothesis that connects low mutation rates in plant mitochondrial DNA (mtDNA) to a lower degree of tissue specialization and a lesser need for a sequestered germline. This hypothesis, however, rests on the premise that we have significant knowledge of plant mtDNA mutation rates, which we do not. As such, intentionally or not, this volume's treatment of the issue conflates our measures of synonymous substitution rates in plant mtDNA (Drouin et al. 2008; Richardson et al. 2013) with mutation rates. These sorts of nuances are glazed over in these digressions but are central to addressing and defining these questions.

A seminar or discussion course with this volume as a guide could be enlightening. Such a course could serve a variety of participants including graduate students, postdoctoral researchers, faculty, or even upper-division undergraduate students. The organization of this book would be useful in bringing a variety of participants from backgrounds across organismal and molecular biology to this discussion, even if they are entirely new to the subject. The first half of the book would give participants a foundation in understanding mitonuclear interactions while, later in the course, the controversial ideas in the second half, supplemented by recent papers including those highlighted by the text, may serve as points of lively debate and discussion.

Whether you agree with its assertions or its characterization of the subfield, this book is a must-read for anyone interested in how mitonuclear interactions impact evolution. The author expounds on many compelling ideas, some of which may eventually provide wide-ranging explanations for evolutionary phenomena, and these ideas deserve consideration and scrutiny. The reader should heed the author's own warning and treat the volume as the point-of-view and impetus for further research that it claims to be, rather than any sort of definitive or even-handed treatment of the subject. This book has the capacity to inspire, or at the very least reorient, anyone working, or who wants to work, at the intersection of mitochondria and evolution.

\section{Abbreviation}

mtDNA: mitochondrial DNA. 


\section{Acknowledgements}

The author is grateful to the Evolution, Ecology, and Behavior program at Indiana University for providing training and funding to be able to perform this work.

\section{Authors' contributions}

LWC is the sole contributor to this manuscript. The author read and approved the final manuscript.

\section{Funding}

This work was supported by the Charles Heiser Fellowship in Plant Evolution awarded by the Indiana University Department of Biology.

\section{Availability of data and materials}

Not applicable.

\section{Competing interests}

The author declares that they have no competing interests associated with the submission of the book review.

Received: 3 July 2020 Accepted: 10 September 2020

Published online: 18 September 2020

\section{References}

Ågren JA. Selfish genes and plant speciation. J Evol Biol. 2013;40:439-49. Barrientos A, Kenyon L, Moraes CT. Human xenomitochondrial cybrids. Cellular models of mitochondrial complex I deficiency. J Biol Chem. 1998;273:14210-7.

Chiyomaru K, Takemoto K. Revisiting the hypothesis of an energetic barrier to genome complexity between eukaryotes and prokaryotes. R Soc Open Sci. 2020;7:191859.
Drouin G, Daoud H, Xia J. Relative rates of synonymous substitutions in the mitochondrial, chloroplast and nuclear genomes of seed plants. Mol Phylogenetics Evol. 2008;49:827-31.

Enoki S, Shimizu A, Hayashi C, Imanishi H, Hashizume O, Mekada K, Sukuzi H, Hashimoto T, Nakada K, Hayashi J. Selection of rodent species appropriate for mtDNA transfer to generate transmitochondrial mito-mice expressing mitochondrial respiration defects. Exp Anim. 1994:63:21-30.

Hampl V, Čepička I, Eliáš M. Was the mitochondrion necessary to start eukaryogenesis? Trends Microbiol. 2019;272:96-104.

Havird JC, Forsythe ES, Williams AM, Werren JH, Dowling DK, Sloan DB. Selfish mitonuclear conflict. Curr Biol. 2019:29:496-511.

Hill GE. Mitonuclear ecology. 1st ed. New York: Oxford University Press; 2019.

Lane N. How energy flow shapes cell evolution. Curr Biol. 2020;30:471-6.

Lane N, Martin W. The energetics of genome complexity. Nature. 2010:467:929-34.

Lane N. Power, sex, suicide: mitochondria and the meaning of life. 1st ed. New York: Oxford University Press; 2005.

Lynch M, Marinov GK. Membranes, energetics, and evolution across the prokaryote-eukaryote divide. Elife. 2017;6:e20437.

Lynch M, Marinov GK. The bioenergetic costs of a gene. Proc Natl Acad Sci USA. 2015;112:15690-5.

Maslow AH. The Psychology of Science: A Reconnaissance. 1st ed. New York: Harper \& Row; 1966.

Richardson AO, Rice DW, Young GJ, Alverson AJ, Palmer JD. The "fossilized" mitochondrial genome of Liriodendron tulipifera: ancestral gene content and order, ancestral editing sites, and extraordinarily low mutation rate. BMC Biol. 2013;14:29.

\section{Publisher's Note}

Springer Nature remains neutral with regard to jurisdictional claims in published maps and institutional affiliations.
Ready to submit your research? Choose BMC and benefit from:

- fast, convenient online submission

- thorough peer review by experienced researchers in your field

- rapid publication on acceptance

- support for research data, including large and complex data types

- gold Open Access which fosters wider collaboration and increased citations

- maximum visibility for your research: over $100 \mathrm{M}$ website views per year

At $\mathrm{BMC}$, research is always in progress.

Learn more biomedcentral.com/submissions 